DOI:

\title{
IMPLEMENTING PRINCIPLE 10 OF THE 1992 RIO DECLARATION: A COMPARATIVE STUDY OF THE AARHUS CONVENTION 1998 AND THE ESCAZÚ AGREEMENT 2018
}

\section{PRINCÍPIO DE IMPLEMENTAÇÃO 10 DA DECLARAÇÃO DE 1992 DO RIO UM ESTUDO COMPARATIVO DA CONVENÇÃO DE AARHUS DE 1998 E DO ACORDO ESCAZÚ 2018}

SIDNEY GUERRA

Pós-Doutor em Direitos Humanos pelo Centro de Estudos Sociais da Universidade de Coimbra; Pós-Doutor pelo Programa Avançado em Cultura Contemporânea da Universidade Federal do Rio de Janeiro (UFRJ). Pós-Doutorando em Environmental International Law (Mackenzie-SP e Stetson University). Doutor e Mestre em Direito (UGF). Professor Associado IV da Universidade Federal do Rio de Janeiro. Professor Titular da Universidade do Grande Rio e Professor Adjunto da Faculdade Presbiteriana Mackenzie Rio. Visiting Researcher pela Stetson University Law School. Advogado. Secretário Municipal de Administração de Duque de Caxias - RJ (2013 2016). Contato: sidneyguerra@terra.com.br.

\section{GIULIA PAROLA}

LLM (Reykjavik, Iceland), Professor in Environmental Law and Post-doc Researcher Scholar, Master in Constitutional Law in South America, Universidade Federal Fluminense, (Niteròi, Rio de Janeiro, Brazil); PhD in Environmental Law in the University of Paris V (France); LLM in the University of Iceland in International Environmental Law; Bachelor of Law, Università degli Studi di Torino (Italy). Email: giuliaparola.law@gmail.com

\section{ABSTRACT}

Twenty years after the signature of the UNECE Convention on Access to Information, Public Participation in Decision-making and Access to Justice in Environmental 
DOI:

Matters, (the Aarhus Convention, 1998) on March 4, 2018 -and after six years of negotiations-,twenty-four countries in Latin American and the Caribbean adopted the Escazú Convention, the first ever legally binding treaty on environmental rights in the Region. The Regional Agreement on Access to Information, Public Participation and Justice in Environmental Matters in Latin America and the Caribbean, once ratified by the signatories, will affect the constitutions and the legislations in Latin America and the Caribbean in environmental matters, serving as a framework to increase the level of the protection on environmental participatory rights in the region. The objective of this article is to give an overview of both treaties. Part I will briefly outline the context and the negotiating process of the two texts. Then, Part II will consist of a comparative analysis, that will scrutinise the structure of the treaties, the notion of democracy and the substantive right to a healthy environment. Finally, the Part III will compare the three pillars recognised in both documents and underline the similarities, the differences between the three pillars, and the steps forwards for Environmental Rights in Latin America and the Caribbean.

KEYWORDS: Right to access; Aarhus Convention; Escazú Agreement; Environmental Democracy; Latin America and Caribbean.

\section{RESUMO}

Vinte anos após a assinatura da Convenção sobre Acesso à Informação, Participação no Processo de Tomada de Decisão e Acesso à Justiça em Matéria de Ambiente UN/ECE (Convenção de Aarhus, 1998) e após seis anos de negociações, vinte e quatro países da América Latina e do Caribe adotaram a Convenção Escazú, o primeiro tratado juridicamente vinculante sobre direito ambiental na Região. O Acordo Regional sobre Acesso à Informação, Participação Pública e Justiça em Matéria de Ambiente na América Latina e no Caribe, uma vez ratificado, produzira efeitos na ordem jurídica interna dos Estados partes em matéria ambiental e servirá para aumentar o nível de proteção dos direitos de participação ambiental na região. $O$ objetivo deste artigo é fornecer uma visão geral de ambos os tratados. A parte I delineará brevemente o contexto e o processo de negociação dos dois textos. A Parte 
DOI:

Il consistirá numa análise comparativa que examinará a estrutura dos tratados, a noção de democracia e o direito substantivo a um ambiente saudável. Por fim, a Parte III se destina a comparar os três pilares reconhecidos em ambos os documentos e sublinhar as semelhanças, as diferenças entre os três pilares e os passos a serem tomados para o Direito Ambiental na América Latina e no Caribe.

PALAVRAS-CHAVE: Acesso à justiça; Convenção de Aarhus; Acordo de Escazú; Democracia Ambiental; América Latina e Caribe

\section{INTRODUCTION}

On March 4, 2018, in the city of Escazú, Costa Rica, twenty years after the signature of the UNECE Convention on Access to Information, Public Participation in Decision-making and Access to Justice in Environmental Matters (UNECE 1998), (the "Aarhus Convention", 1998), hereinafter Aarhus, after six years of negotiations, twentyfour countries in Latin American and in the Caribbean adopted the Escazú Convention on Access to Information, Participation and Justice in Environmental Matters in Latin America and Caribbean by ECLAC (ECLAC, 2018) (hereinafter, Escazú), the first legally binding treaty on environmental rights in the Region.

The Regional Agreement, once ratified by the Countries, will affect the constitutions and the legislations in Latin America in environmental matters, serving as a framework to increase the level of the protection on environmental participatory rights in the region.

This article will compare the Aarhus and the "Escazú" (GASTÓN MÉDICI, 2018). Aarhus was the first international treaty that implemented Principle 10 of Rio Declaration on environmental Access Rights1, that establishing a process of

\footnotetext{
1 Declaration on Environment and Development, Principe 1, Report of the UN Conference on Environment and Development (UNCED). The UNCED was held in Rio de Janeiro (Brazil) from 3 to 14 June 1992 and was attended by 178 States, more than 50 intergovernmental organisations and several hundred non-governmental organisations (NGOs). The European Union also attended the Conference. In addition to the signing by more than 150 States of the United Nations Framework Convention on Climate Change and the Convention on Biological Diversity, the Conference adopted three non-binding instruments: the Rio Declaration, the UNCED Forest Principles and Agenda 21.
} 
DOI:

assessment that includes individuals and their right? to exercise control over acts of government, thereby participating and contributing to decision-making in environmental matters (PAROLA, 2017). Principle 10 provides that:

Environmental issues are best handled with participation of all concerned citizens, at the relevant level. At the national level, each individual shall have appropriate access to information concerning the environment that is held by public authorities, including information on hazardous materials and activities in their communities, and the opportunity to participate in decision-making processes. States shall facilitate and encourage public awareness and participation by making information widely available. Effective access to judicial and administrative proceedings, including redress and remedy, shall be provided.

According to the former Secretary-General of the United Nations, Kofi Annan

is:

By far the most impressive elaboration of principle 10 of the Rio Declaration, which stresses the need for citizen's participation in environmental issues [...] As such it is the most ambitious venture in the area of environmental democracy so far undertaken under the auspices of the United Nations (ANNAN, 2000, p. 17).

In this sense, it represents the first international convention aimed at creating trans-boundary environmental procedural rights of individuals (access to information, participation and access to justice) in the move towards an environmental democracy (ECKERSLEY, 2004, p. 104).

The Escazú Agreement is also an implementation of Principle 10 and in the words of Alicia Bárcena, Executive Secretary Economic Commission for Latin America and the Caribbean (ECLAC):

Visionary and unprecedented, it is an agreement reached by and for Latin America and the Caribbean, reflecting the ambition, priorities and particularities of our region. It addresses key aspects of environmental management and protection from a regional perspective (...) The strong regional commitment to environmental protection and human rights is expected to lead to the Regional Agreement's prompt entry into force. By joining this landmark treaty, the 33 countries of Latin America and the Caribbean will not only continue to strengthen environmental democracy, but will also move a step closer towards making equality, sound economic growth and sustainable development for all a reality. (BARCEN, 2018, p. 5). 
DOI:

This new Agreement, as the Aarhus Convention was for Europe and also for some countries in Asia, could serve as a catalyst, if not as a model, for the construction of an environmental democracy in Latin America and an improvement for environmental law.

The article will first give an overview of both documents, in particular in Part I it will briefly outline the context and the negotiating process of the two texts. Then, Part II will consist of a comparative analysis, illustrating the structure of the two conventions, the notion of democracy and the substantive right to a healthy environment. Finally, the Part III will compare the three pillars recognised in both documents and underline the similarities, the differences between the three pillars, and the steps forwards for Environmental Rights in Latin America and the Caribbean. (ALONSO, 2018; WORLD RESOURCES INSTITUTE, 2018).

\section{IMPLEMENTATION OF PRINCIPLE 10: AARHUS CONVENTION AND ESCAZÚ AGREEMENT}

\section{1 "AARHUS"}

The Aarhus Convention was signed on 25 June 1998 in Aarhus, Denmark, and entered into force on 30 October 2001, ninety days after the deposit of the sixteenth instrument of ratification, and as of 26 September 2012, it counts 47 Parties. 2

The Convention was the first implementation of Principle 10 of the Rio Declaration, and in the Paragraph 2 of the Preamble it refers to the principle that drew attention to the creation of new procedural rights: "Environmental issues are best handled with the participation of all concerned citizens at the relevant level".

The participatory norms embodied in Principle 10 have, more than many aspects of international environmental law, challenged traditional ideas and limits of both international law and municipal law (ANTON, 2008, p. 8). In other words, this norm

\footnotetext{
247 March 2017: the signatory nations include almost all the nations of Europe and most of the former Soviet Socialist Republics, but not Russia. For a list of nations participating in the treaty, see Convention on Access to Information, Public Participation in Decision- Making and Access to Justice in environmental Matters, Participants, Available: UNECE.
} 
DOI:

appears to open up areas of a state's domain réservé (ANTON, 1993, p. 553). The inward bearing of these international participatory norms has the potential to invade fundamental aspects of the state including state secrecy, legal procedure, and public administration.

Indeed, the norms elaborated in Principle 10 have been seen by some commentators as an attempt to break the external "sovereignty barrier" 3 by granting participatory rights on individuals and other non-state actors in fundamental aspects of the international system such as international law-making and monitoring compliance with and enforcing breaches of international law (ANTON, 2008, p. 8; DONALD, 2008).

In other words, this norm has tried to stir up the basis of environmental governance and introduce a participatory element of the environmental democracy model. Article 1 of Aarhus Convention is an example of such approach, stating:

In order to contribute to the protection of the right of every person of present and future generations to live in an environment adequate to his or her health and well-being, each Party shall guarantee the rights of access to information, public participation in decision-making, and access to justice in environmental matters.

This provision underlines, unlike most multilateral environmental agreements which cover obligations that Parties have to each other, that the Aarhus Convention imposes a clear obligation on its Parties and public authorities towards the "public", as far as access to information, public participation and access to justice are concerned (STEC, CASEY-LEFKOWITS, 2000, p. 1).

Article 1 also outlines the role of the State in reaching this goal. Thus, it is up to the State to provide for the necessary administrative, legal and practical structures, which shall guarantee the basic three rights, covered by the Convention. This represents a new approach to the role of the State. Instead of solving ecological problems itself, the State acts as a sort of referee in a process involving larger social forces, leading to a more organic and complete result.

\footnotetext{
${ }^{3}$ The term "sovereignty barrier" is taken from an an Article appearing in an NGO newspaper for the 1992 United Nations Conference on Environment and Development (UNCED). Sovereignty Barrier to environmental Law, Crosscurrents, August 14-15, 1991, p. 2, col. 1.
} 
DOI:

From the spatial dimension point of view, the Aarhus aims at influencing international practice beyond the limits of the UNECE. Despite this treaty being principally a vehicle for promoting access to environmental decisions at a domestic level, the spatial approach of the Convention has also been reinforced by global ambitions. 4

There is a wide selection of evidence for this approach. First, proponents of the Convention have often looked at the possibility of exporting the agreement. The implementation guide (STEC, CASEY-LEFKOWITS, 2000, p. 1) notes that the convention is "open to accession by non-ECE countries, giving it the potential to serve as a global framework for strengthening citizens' environmental rights". Second, the global relevance of the Convention is further confirmed by the influence that this Convention has on the drafting process of the "Escazú Agreement " (GASTÓN MÉDICI, 2018).

\subsection{A "ESCAZÚ AGREEMENT"}

Over the past twenty years the countries of the Latin American and Caribbean have made great progress in recognizing the right of access to information, participation in decision-making and access to justice on environmental matters (PAROLA, 2016; ECLAC, 2012) ${ }^{5}$. Despite some progress, many countries are finding difficult to apply in practice/implement such right and the adoption of a regional instrument on environmental access rights could help to improve the situation (ECLAC, 2013)6.

Before analysing the process towards the adoption of the mentioned regional agreement, it is important to answer this question: why is it necessary to have a new regional instrument if the Aarhus Convention is open to every country and not only to

\footnotetext{
${ }^{4}$ In the words of the former Secretary-General: "Although regional in scope, the significance of the Aarhus Convention is global". This actually exemplifies the "desire of UNECE to continue to produce environmental agreements that are at least potentially beneficial at the global level'.

${ }^{5}$ See Examples are Mexico's federal law on transparency and access to public government information (2002), Chile's law on access to public information (2009), and Peru's law, enacted in 2011, on indigenous peoples' right to prior consultation, as recognized in Convention 169 of the International Labour Organization (ILO).

${ }^{6}$ Many examples of progress and difficulties in: ECLAC 2013. This document reviews laws and institutional frameworks that safeguard Principle 10 of the Rio Declaration.
} 
DOI:

the European countries? Indeed the Latin American countries could have signed the Aarhus Convention without starting a new process to adopt an other treaty on the same topic.

One of the specific arguments for advancing towards a regional convention is that the social, historical and economic context, the issues and problems in this region are different from Europe. For instance in Latin America there are sectors of society that have historically been marginalised from decision-making on issues relating to the environment. To this end, steps has been taken in the new agreement, and also before the drafting process, to build the capacity of groups of persons that have traditionally been underrepresented in participatory processes. For this reason, the Escazú Agreement, as it will be underlined in several occasions in this paper, takes an extra special care of those persons, including indigenous populations and local communities, and this involves also the recognition of their traditional knowledge.

Moreover, another argument is that Latin American and Caribbean countries share common cultural bonds and a regional convention could take into account specific national characteristics and the historical and social specificities of this region.

Finally, as mentioned in a declaration of the ECLAC, one more reason for advancing towards a new Agreement was to send:

[...] a strong signal to other countries and foreign investors of the commitment of the signatory countries to good governance, and of the belief that genuine public participation leads to better-quality decision-making in environmental matters and greater confidence in decisions made by government (BALMACEDA, 2012, p. 66).

Thus, the process towards the adoption of a regional agreement began with the Declaration on the application of Principle 10 in Latin America and the Caribbean adopted in the framework of the United Nations Conference on Sustainable Development (Rio+20) in June 2012 (ECLAC, (2014)7.

\footnotetext{
7 The future we want (Rio+20). In 2012, the United Nations Conference on Sustainable Development (Rio+20) was held in Rio de Janeiro. Rio+20 culminated with the final document "The Future We Want", which covers a diversity of topics relevant to Principle 10: democratic institutions and the rule of law, environmental information, corporate responsibility, strengthening of the United Nations Environment Programme and regional efforts, including the instrument on Principle 10 in Latin America and the Caribbean.
} 
DOI:

By means of the Declaration, with the support of the ECLAC as technical secretariat, the signatory countries committed themselves to work towards a regional agreement on the rights of environmental access to information, public participation and access to justice. Between 2012 and 2014, four meetings of the focal points of the signatory countries and fourteen meetings of working groups were held.

In November 2014, the countries launched the negotiation phase of the regional agreement and established a Negotiating Committee with a view to concluding the negotiations by December 2017. The Negotiating Committee was composed of the signatory countries with the significant participation of the public and met for the first time in Santiago in May 2015. At that meeting, it adopted its organisation and work plan which established that countries would continue with their national consultations on the preliminary document of the regional agreement prepared by ECLAC and submit language proposals on the document by 31 August 2015. The Committee met again in Panama City (October 2015) and Montevideo (April 2016), in Santo Domingo (August 2016) in Santiago (November 2016) in Brasilia (March 2017), in Buenos Aires (August 2017) in Santiago (November 2017) and in March 2018 in Escazú the agreement was adopted. The Agreement was negotiated by 24 Countries in Latin America e Caribbean but the signature and ratification is open to the 33 Countries of the Region. The ECLAC has underlined how the agreement "is not only about including more countries, but fundamentally, about reaching more people and improving their quality of life. This agreement is an agreement between governments and their citizens and the potential here is great: 500 million people" (ECLAC, 2016, p. 16).

\section{AARHUS AND ESCAZÚ AGREEMENT: THE STRUCTURE, THE NOTION OF DEMOCRACY AND THE SUBSTANTIVE RIGHT TO A HEALTHY ENVIRONMENT}

\subsection{THE STRUCTURE}

It is important to note, as a preliminary comparative overview, that the structure of the Escazú corresponds to the Aarhus: there is a symmetry between their respective articles and the content. In particular, Article 1 is dedicated to the "Objective" in both 
DOI:

documents; Article 2 deals with the "Definitions" also in both texts; then Article 3 in Aarhus and Article 4 in Escazú are on the "General Provisions". An important difference marking a step forward in the new Agreement is Art. 3 on "Principles, -not present in the Aarhus, which provides that, both in the implementation and in the interpretation of the three pillars, each Party shall be guided by the following principles:

(a) Principle of equality and principle of non-discrimination; (b) Principle of transparency and principle of accountability; (c) Principle of non-regression and principle of progressive realization; (d) Principle of good faith; (e) Preventive principle; (f) Precautionary principle; (g) Principle of intergenerational equity; (h) Principle of maximum disclosure; (i) Principle of permanent sovereignty of States over their natural resources; (j) Principle of sovereign equality of States; and (k) Principle of pro persona.

Among others, it is particularly noteworthy the principle of "non-regression and principle of progressive realization" that receives recognition in an environmental binding agreement for the first time that the principle of non-regression, in the words of Michel Prieur, "prohibits any recession of environmental law or existing levels of environmental protection, and comprises its protective norms in the category of nonrevocable and intangible legal rules, in the common interest of humanity" (PRIEUR, 2013, p. 5). A definition of the two principles had already been provided, by IUCN World Declaration on the Environmental Rule of Law, adopted during the IUCN World Congress on Environmental Law, held in Rio de Janeiro (Brazil) in 20168:

Principle 12 Non-regression: States, sub-national entities, and regional integration organisations shall not allow or pursue actions that have the net effect of diminishing the legal protection of the environment or of access to environmental justice. Principle 13 Progression: In order to achieve the progressive development and enforcement of the environmental rule of law, States, sub-national entities, and regional integration organisations shall regularly revise and enhance laws and policies in order to protect, conserve, restore, and ameliorate the environment, based on the most recent scientific knowledge and policy developments.

In a comparative perspective, the three pillars (access to information, public participation and access to justice) are similar in content and in structure. In both documents, the first pillar includes both the "passive" and the "active" feature of the

8 The IUCN World Congress on Environmental Law, held in Rio de Janeiro (Brazil) from 26 to 29 April 2016 
DOI:

access to information. The passive one is covered by Article 4 "Access to Environmental Information" in Aarhus and by Article 5 "Access to environmental information" in the Escazú; that is, the obligation for public authorities to respond to public requests for information.

The "active" aspect is provided by Article 5 "Collection and Dissemination of Environmental Information" in Aarhus and by Article 6 "Generation and dissemination of environmental information" in the Escazú Agreement. It involves the right of the public to obtain information and the obligation of authorities to collect and disseminate information of public interest without the necessity of a precise request.

The second pillar on public participation is developed in Aarhus in three Articles (Art. 6 "Public Participation in Decisions on Specific Activities", Art.7 "Public Participation Concerning Plans, Programmes and Policies relating to the Environment" and Art. 8 "Public Participation During the Preparation of Executive Regulations and/or Generally Applicable Legally Binding Normative Instruments") and in the Escazú Agreement the participation pillar is contained in Article 7 on "Public participation in environmental decision-making".

Then about the last pillar, Article 9 in Aarhus and Article 8 in Escazú deal both with Access to justice in environmental matters. This pillar deal with access to justice in two situations: first, it protects/strengthens the other two pillars, by providing access to review procedures in relation to information and access to review procedures to challenge decisions, acts, or omissions subject to the public participation provisions 9 .

Finally, it is important to anticipate and it will be better analyse later, that Article 9 in the Escazú agreement includes the world's first binding provision on human rights defenders in environmental matters. This is essential in a Region where sadly the human rights defenders are too often subject to murders, attacks and intimidations (GLOBAL WITNESS REPORT, 2017).

\footnotetext{
9 In the Aarhus convention is called "Access to Justice" and in the Escazú Agreement is called "Access to justice in environmental matters".
} 
DOI:

\subsection{THE NOTION OF DEMOCRACY}

The Aarhus Convention was conceived with the express aim of promoting democracy to solve, at the same time, the problem of democratic deficit, as well as protecting the rights of everyone to live in a healthy environment. The agenda of Aarhus was mainly determined by a concern to get the newly independent states of Central and Eastern Europe closer to the European Union's standard of environmental protection, and the "democratic component was considered crucial to this end" (HAYWARD, 2000, p. 558).

Consequently, drafters and commentators alike claimed that "the experience of the former communist bloc testified to a direct correlation between deficits in democracy and environmental quality. In fact, access to reliable information on the environment and recognition of the role of NGOs in raising the level of public awareness of environmental issues were seen as prerequisites to developing a civil society of democratic citizenry" (HAYWARD, 2000, p. 558).

For this reason, in its preamble, the contracting parties state their belief "that the implementation of this Convention will contribute to strengthening democracy in the region of the United Nations Economic Commission for Europe" (DECLARATION BY THE ENVIRONMENTAL MINISTERS, 1998).

The Escazú Agreement recognises in the Preamble that the same approach:

"Convinced that access rights contribute to the strengthening of, inter alia,
democracy, sustainable development and human rights", and that Recalling
also that, (...) democracy, good governance and the rule of law, at the national
and international levels, as well as an enabling environment, were essential
for sustainable development $(. .$.$) ". And then always in the Preamble the new$
agreement recognise "the important work of the public and of human rights
defenders in environmental matters for strengthening democracy, access
rights and sustainable development and their fundamental contributions in this
regard".

It is important to underline that, especially for Latin American and Caribbean, an effective democracy must include those groups of persons that have traditionally been underrepresented in participatory processes, for this reason Article 2 of the Escazú Agreement introduces a definition, that it was not in the Aarhus, of 
DOI:

(e) "Persons or groups in vulnerable situations" means "those persons or groups that face particular difficulties in fully exercising the access rights recognised in the present Agreement, because of circumstances or conditions identified within each Party's national context and in accordance with its international obligations.

Above all, this treaty aims to combat inequality and discrimination and for the first time in international environmental law, the Convention requires governments to ensure that vulnerable populations, like Indigenous Peoples or underrepresented communities, can exercise their full rights to information, participation and justice and to participate effectively to the democracy (PAROLA, 2017).

It is clear by the terminology adopted in both documents that democracy is fundamental for a government to reach environmental goals, the notion of democracy is based on the right to information as a prerequisite for the effective exercise of the rights to political participation and access to justice, which completes the "triptych" of the procedural rights of "environmental democracy". In this sense, these rights "give practical form, in the specific context of environmental policy, to the general principles of democracy and the rule of law already enshrined in other international prescriptive instruments on the protection of human rights" (PALLEMAERTS, 2003).

Moreover, the most important common point is that both texts grant the right to everyone to participate, and they consider that general public involvement offers a better answer to the environmental crisis.

Although the introduction of participatory rights brings a fundamental element of participatory democracy to the environmental decision-making process, the Aarhus model, followed also by the Escazú Agreement, is to supplement representative democracy with participatory democracy.

The supremacy of representative institutions and the narrow role of public participation are evident throughout both documents. The participation process is directed and controlled by predetermined public authorities. The role of the public appears limited to a contribution to the technical assessment of the alternatives, and the public authorities determine which of the alternatives are the best "means" to a predefined "end". Thus, the institutions of representative democracy are the authoritative decision makers. 
DOI:

The public is not given the right to initiate a participation process, organise or set its timetable. According to Article 6(8) in the Aarhus, public authorities must follow the consultation procedure and they must "ensure that in their decision due account is taken of the outcome of the public participation". However, they are not bound to accept or act on the comments of any of the participants. The same approach is followed by the Escazú Agreement, in the Article 7(7):

\begin{abstract}
The public's right to participate in environmental decision making processes shall include the opportunity to present observations through appropriate means available, according to the circumstances of the process. Before adopting the decision, the relevant public authority shall give due consideration to the outcome of the participation process". And the article 7(8) "Each Party shall ensure that, once a decision has been made, the public is informed in a timely manner thereof and of the grounds and reasons underlying the decision, including how the observations of the public have been taken into consideration. The decision and its basis shall be made public and be accessible.
\end{abstract}

It can be said that taking into account the outcome of public participation does not require the relevant authority to accept "the substance of all comments received and to change the decision according to every comment". The public authorities should treat comments from the public as "information to be added to the information that they have from other sources" STEC, 2000, p.119).

The wide liberty provided to the institutions of representative democracy supports the interpretation that the "democratisation" stipulated by Aarhus and by Escazú Agreement is an attempt to face the democratic deficit with respect to concrete environmental matters (BELL, 2004, p. 98).

\title{
3.3 THE SUBSTANTIVE RIGHT TO A HEALTHY ENVIRONMENT
}

Principally, the Convention's and the Agreement's primary focus is not on the substantive right to a healthy environment, but rather on procedural rights in environmental decision-making.

The Aarhus Preamble, hence, recognises that: "adequate protection of the environment is essential to human well-being and the enjoyment of basic human rights, 
DOI:

including the right to life itself" and "also that every person has the right to live in an environment adequate to his or her health and well-being".

The preliminary text of the Escazú Agreement in the Preamble (8) recognised also that:

Everyone has the right to a healthy environment in harmony with nature, which is essential for the full development of human beings and for the achievement of sustainable development poverty eradication, equality, and the preservation and stewardship of the environment for the benefit of present and future generations.

Unfortunately in the last version of the agreement this paragraph was deleted and actually in the last version the right to a healthy environment appears in Article 1 as an objective and not as a substantive right:

\begin{abstract}
The objective of the present Agreement is to guarantee the full and effective implementation in Latin America and the Caribbean of the rights of access to environmental information, public participation in the environmental decisionmaking process and access to justice in environmental matters, and the creation and strengthening of capacities and cooperation, contributing to the protection of the right of every person of present and future generations to live in a healthy environment and to sustainable development.
\end{abstract}

The explicit acknowledgment of the right in both documents adds weight to its operative provisions for the implementation of procedural rights. Thus, the meaning of the above-mentioned sentences shows that the procedural rights are not end in themselves, "but are meaningful precisely as means towards the end of protecting the individual's substantive right to live in a healthy environment" (PALLEMAERTS, 2002, p. 18).

Furthermore, Article 1 in the Aarhus, mentioned above, instructs Parties on how to move towards the establishment of the guarantee of the basic right of present and future generations to live in an environment adequate to health and well-being, saying that in order to contribute to the protection of the right "each Party shall guarantee the rights of access to information, public participation in decision-making, and access to justice (...)".

The last version of Article 1 of the Escazú Agreement is going also in this direction affirming 
DOI:

The objective of the present Agreement is to guarantee the full and effective implementation (...) of the rights of access to environmental information, public participation in the environmental decision-making process and access to justice in environmental matters, (...) contributing to the protection of the right of every person of present and future generations to live in a healthy environment.

It may be noted that the literal meaning of both provisions is that the parties acknowledge that guaranteeing the rights laid down in the convention will not in itself be sufficient to ensure the protection of the substantive right, but will only contribute to the achievement of that ultimate objective. Both norms establish "the linkage between practical, easily understandable rights, such as those relating to information and decision-making, and the harder-to-grasp complex of rights included in the right to a healthy environment" (STEC, 2000, p. 29).

To sum up, the protection of the right to a healthy environment is presented in inspirational terms as an objective that Aarhus and the Escazú intend to achieve, but not as a "substantive obligation distinct from the specific obligations with respect to access to information, participation and access to justice which it imposes on its contracting parties" (PALLEMAERTS, 2004, p. 18). On the basis of both documents, which protect in theory the procedural rights of present generations, the substantive right is only framed in a procedural dimension.

\section{THE THREE PILLARS APPROACH: SIMILARITIES, DIFFERENCES, AND STEPS FORWARDS}

Both texts have the aim to implement Principle 10, and as the documents' full name suggests, in the form of three pillars: access to information, public participation and access to justice. Both documents ${ }^{10}$ remind to the Parties that the Convention's provisions are minimum requirements and that Parties have the right to provide broader access rights.

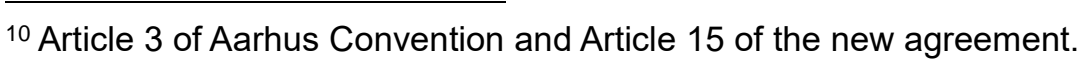


DOI:

\subsection{FIRST PILLAR: ACCESS TO ENVIRONMENTAL INFORMATION}

Access to information constitutes the first of the three pillars and is the essential starting point for any public involvement in decisions. It is also able to stand alone, since the public may ask for access to information for any reason, not just for the purpose of participating. The pillar guarantees that members of the public are conscious of what is occurring in their adjacent environment and moreover aims that the public is competent to participate in an informed manner. In both documents, the first information pillar includes both the "passive", and the "active" aspect.

\subsubsection{Passive Access}

Article 4 of Aarhus sets out a framework through which members of the public can access environmental information from public authorities. Once a member of the public has requested information, Article 4 establishes criteria and procedures for obtaining or refusing such access (STEC, 2000, p. 53).

Paragraph 1 includes the general obligation for public authorities to grant environmental information in response to a request. The right of access extends to any person, without him or her having to prove or even state an interest. A request can be any communication by a member of the public to a public authority soliciting environmental information (STEC, 2000, p. 53).

As already said, all persons have the right of access to information and the Convention provides a general rule of freedom of access to information. As a result, requests cannot be rejected even in cases where the claimant does not hold an interest in the information. Public authorities shall not call for any requirements which entail that the claimant has to show his or her motivation for receiving the information or how he or she intends to use it. The Convention obliges public authorities to supply the information "as soon as possible". It subsequently establishes a maximum time limit of one month. Nevertheless, public authorities in certain circumstances have the possibility under the Convention to find that the "volume and complexity" of the information excuses an extension of the one-month time limit to two months. In such situations, the authority must inform the claimant of this extension, by giving the 
DOI:

reasons therefore, as soon as possible and at the latest by the end of the first month (STEC, 2000, p. 53).

Concerning the passive access to information, the Escazú Agreement in the Art. 5 follows the Aarhus article with one important difference, in paragraphs 3 and 4 :

3. Each Party shall facilitate access to environmental information for persons or groups in vulnerable situations, establishing procedures for the provision of assistance, from the formulation of requests through to the delivery of the information, taking into account their conditions and specificities, for the purpose of promoting access and participation under equal conditions. 4. Each Party shall guarantee that the above-mentioned persons or groups in vulnerable situations, including indigenous peoples and ethnic groups, receive assistance in preparing their requests and obtain a response.

This provision is linked to the definition in Article 2 (e) of "Persons or groups in vulnerable situations", analysed before, entailing that the beneficiaries of this agreement are also persons or groups in vulnerable situations.

\subsubsection{Active Access}

Article 5 of the Aarhus and Article 6 of the Escazú establish the obligation of the government to collect and disseminate environmental information. The recognition of this right reflects the deliberative and participatory theories in which the informed citizen is seen as a step closer to awareness and participation, than the uninformed.

It includes an extensive variety of different categories of information that the State should supply to members of the public. Usually, it comprises information such as emergency information, product information, pollutant release and transfer information, information about laws, policies and strategies, and methods of recording information.

The Aarhus obliges the States to establish internal processes to ensure the ample flow of all significant environmental information and in addition it concentrates on the real implementation of procedures for collecting and distributing information related to any threat to human health or the environment. 
DOI:

The above-mentioned requirements apply to private bodies that cooperate with governmental agencies, although the provision frames is as a unilateral obligation of the State (CRAMER, 2009, p. 98).

Moreover, the State shall also encourage any private person to inform the public with regard to all activities and products which could have an impact on the environment, within the framework of voluntary labelling or auditing schemes.

Parties are required to "progressively" make environmental information publicly available in electronic databases, which can easily be accessed through public telecommunications networks WATES, 2005, p.2). Finally, the Convention requires that all parties publish, every three/four years, a national report on the state of the environment CRAMER, 2009, p. 97-99).

Article 6 of Escazú, that substantially follows article 5 of Aarhus, provides that parties shall guarantee:

[...] that the competent authorities generate, collect, publicize and disseminate environmental information relevant to their functions in a systematic, proactive, timely, regular, accessible and comprehensible manner, and periodically update this information and encourage the disaggregation and decentralization of environmental information at the subnational and local levels.

Then, also Article 6(6) recalls, the already mentioned approach, to help facilitate access by groups in vulnerable situations to information that particularly affects them, and moreover each Party shall also endeavour "where applicable, to ensure that the competent authorities disseminate environmental information in the various languages used in the country, and prepare alternative formats that are comprehensible to those groups, using suitable channels of communication."

Finally, like in Aarhus, Article 6 (7) of Escazú requires that all parties publish, at regular intervals, not exceeding five years, a national report on the state of the environment, but this paragraph marks a step forward, by adding the details on the report and the possibility for the public to make contributions to it. Thus, the national report on the state of the environment may contain:

(a) information on the state of the environment and natural resources, including quantitative data, where possible; (b) national actions to fulfil 
DOI:

environmental legal obligations; (c) advances in the implementation of the access rights; and (d) collaboration agreements among public, social and private sectors. Such reports shall be drafted in an easily comprehensible manner and accessible to the public in different formats and disseminated through appropriate means, taking into account cultural realities. Each Party may invite the public to make contributions to these reports.

\subsection{SECOND PILLAR: ENVIRONMENTAL PARTICIPATION}

Public participation constitutes the second pillar of the two documents. Its importance is fundamental because it is the link between the other two pillars: public participation cannot be effective without access to information, as provided under the first pillar, nor without the possibility of enforcement, through access to justice under the third pillar.

Aarhus distinguishes between two kinds of public in Art 2(4): the "public" and the "public concerned". "The public" means "one or more natural or legal persons, and, in accordance with national legislation or practice, their associations, organizations or groups" and in Art. 2(5) the "public concerned" means

[...] the public affected or likely to be affected by, or having an interest in, the environmental decision-making; for the purposes of this definition, nongovernmental organisations promoting environmental protection and meeting any requirements under national law shall be deemed to have an interest.

The Escazú Agreement does not distinguish the public and, in the Article 2, gives just one definition and in this manner avoids the problem that exists in Aarhus to verify if the individual or organisations are included or not. The definition of "Public" in the new agreement means "one or more natural or legal persons and the associations, organizations or groups established by those persons, that are nationals or that are subject to the national jurisdiction of the State Party". Thus, for Escazú, any member of the public has the right to submit comments, information, analyses or opinions for the duration of the public participation procedures. The public authority cannot refuse any of such comments, information, analyses or opinions by arguing that the specific individual was not a part of the public concerned. 
DOI:

With regard to the Second Pillar, the Aarhus was considered "novel' by 'go[ing] well beyond familiar techniques of consulting neighbours over sitting decisions" (STEC, 2000 , p. 92) to foresee public participation in decision making at three stages: 1 . in "decisions on specific activities" (Article 6); 2. concerning plans, programs and policies relating to the environment, (Article 7); and 3 . in relation to the preparation of executive regulations and/or generally applicable legally binding normative instruments (Article 8).

In the Escazú Agreement the public participation is regulated in Article 7 on " Public participation in the environmental decision-making process"11. This provision includes approximately the content of Article 6 and Article 7 of the Aarhus. The content of Article 8 in Aarhus is not corresponding to any article in the new agreement and for this reason it will be not analysed.

\subsubsection{Public participation in decisions on specific activities}

Article 6 in Aarhus concerns participation in decisions permitting certain activities listed in Annex I of the Convention; for example, activities within chemical installations and waste management, or other activities which may have a significant effect on the environment. The public has the opportunity to react to and defend itself against proposals for activities with significant environmental impacts.

Article 6 generally includes activities subject to the environmental impact assessment (EIA), procedure under the UNECE Espoo Convention on environmental Impact Assessment in a Trans-boundary Context.12

\footnotetext{
11 It important to underline that the explanation about the term "Decision-making in environmental matters" was made by the Article 2 but in the last version of Escazú was deleted because the Parties did not find a agreement about it, "the development, implementation, compliance and evaluation of laws and regulations, policies, plans, strategies, programmes, projects - whether public or private liable to affect the environment or the use, exploitation or conservation of natural resources at all levels of the internal government structure(...)"

${ }^{12}$ An activity originally omitted from the mandatory requirements of Article 6 was decision-making concerning genetically modified organisms. However, at their second meeting in May 2005, the Meeting of the Parties adopted an amendment imposing a public participation requirement in decisions on the deliberate release and placing on the market of genetically modified organisms. Participation should commence already early in the process, when options are still open, and moreover, due account must be taken of the result of public participation.
} 
DOI:

The Escazú Agreement does not rule on "specific activities" and the Article $7(1)$ has a more general approach, providing that "Each Party shall ensure the public's right to participation and, for that purpose, commits to implement open and inclusive participation in environmental decision-making processes based on domestic and international normative frameworks.". Then paragraph 2 adds that

\begin{abstract}
Each Party shall guarantee mechanisms for the participation of the public in decision-making processes, revisions, reexaminations or updates with respect to projects and activities, and in other processes for granting environmental permits that have or may have a significant impact on the environment, including when they may affect health.
\end{abstract}

Art 7(4) in Escazú Agreement is strengthening public participation by providing that governments must involve the public "early", " from the early stages, so that due consideration can be given to the observations of the public, thus contributing to the process" and by stating that after a decision has been made, they must inform citizens on how their input shaped the final outcome (Art. 7(5)).

4.2.2 Public Participation Concerning Plans, Programmes and Policies Relating to the Environment

Article 7 in Aarhus requires parties to make "appropriate practical and/or other provisions for the public to participate during the preparation of plans and programmes relating to the environment". Commentators have noted that the term "relating to the environment" is wide, "covering not just plans or programmes prepared by an environment ministry, but also sectoral plans such as transport, tourism, where these have significant environmental implications" (WATES, (2005, p. 6).

Quite similar and wide is the content of article 7(3) of Escazú that provides:

Each Party shall promote the participation of the public in decision-making processes, revisions, re-examinations or updates other than those referred to in paragraph 2 of the present article with respect to environmental matters of public interest, such as land-use planning, policies, strategies, plans, programmes, rules and regulations, which have or may have a significant impact on the environment. 
DOI:

It must be underlined that the new agreement goes beyond Aarhus in Article 7(10 and 11), and also in the following paragraphs:

10. Each Party shall establish conditions that are favourable to public participation in environmental decision-making processes and that are adapted to the social, economic, cultural, geographical and gender characteristics of the public. 11. When the primary language of the directly affected public is different to the official languages, the public authority shall ensure that means are provided to facilitate their understanding and participation.

Then, Article 7(13) provides that, in order to facilitate the participation, the parties shall establish "appropriate spaces for consultation on environmental matters or the use of those that are already in existence in which various groups and sectors are able to participate." and also they shall "promote regard for local knowledge, dialogue and interaction of different views and knowledge, where appropriate".

Finally, paragraph 14 and 15 of Article 7, also following the regional approach, affirms that:

14. The public authorities shall make efforts to identify and support persons or groups in vulnerable situations in order to engage them in an active, timely and effective manner in participation mechanisms. For these purposes, appropriate means and formats will be considered, in order to eliminate barriers to participation. 15. In the implementation of the present Agreement, each Party shall guarantee that its domestic legislation and international obligations in relation to the rights of indigenous peoples and local communities are observed.

\subsection{THIRD PILLAR: ACCESS TO JUSTICE}

Article 9 in Aarhus and article 8 in Escazú deal with access to justice in two situations: first, it protects/strengthens the other two pillars, by providing access to review procedures in relation to information and access to review procedures to challenge decisions, acts, or omissions subject to the public participation provisions. Second, Article 9 it also "points the way to empowering citizens and NGOs to assist in the enforcement of the law" and also helps to overcome difficulties "such as the non- 
DOI:

transposition into domestic law of international treaty obligations which are of a nonself-executing character"(REDGWELL, 2007, p. 159).

Article 9(1) in Aarhus acknowledges that any person, who believes that his or her request for information was ignored, wrongfully refused, or inadequately answered, has, in accordance with national law, access to a judicial or non-judicial review procedure.

Under this provision, any person has a right to exercise the review procedures and has a legal standing to challenge decisions made under Article 4 of Aarhus. Moreover, Article 9(1) in Aarhus is in conformity with Article 4's language, which grants any member of the public the right to request information. In addition, the first paragraph provides that the review procedure must be set before "a court of law or any other independent and impartial body established by law".

Following the same path, Article 8(2a) in the New Agreement provides the protection of the first pillar: "Each Party shall ensure, in the framework of its domestic legislation, access to judicial and administrative mechanisms to challenge and appeal, with respect to substance and procedure: (a) any decision, action or omission related to the access to environmental information".

Then, paragraph 2 of Article 9 in Aarhus provides that members of the public and any NGOs that have sufficient interest or that maintain "impairment of a right where the administrative procedural law of a Party requires this as a precondition" are able to "challenge the substantive or procedural legality of any decision, act or omission" under Article 6, and also any decision under other relevant provisions of the Convention (KRAVCHENKO, 2003 p. 27). Also in Escazú, Article 8(2b) strengthens the second pillar. The Parties shall ensure access to judicial and administrative mechanisms to challenge and appeal: "(b) any decision, action or omission related to public participation in the decision-making process regarding environmental matters."

Finally Article $9(3)$ in Aarhus can be considered a fourth pillar (JOHANNSDOTTIR, 2008, p. 221), because it provides access to administrative or judicial procedures to challenge acts and omissions by private persons and public authorities which breach environmental law (MARSHALL, 2006, p. 106). Similar provision can be found in the Article 8(2c) in Escazú, when it affirms that the Parties shall ensure access to judicial and administrative mechanisms to challenge and appeal 
DOI:

: "(c) any other decision, action or omission that affects or could affect the environment adversely or violate laws and regulations related to the environment."

Article 9 (3) in Aarhus and Article 8(2c) in Escazú are not linked with the other pillars, but it should be considered as a new right recognised by both documents. The specificity of this form of "external review" (REDGWELL, 2007, p. 169) has led to consider it as a fourth pillar (JOHANNSDOTTIR 2008, p. 22) of the Convention and the same approach can be used also to interpret the Article 8 in the New Agreement. This special consideration is also due to the fact that it has no connection with either of the first two pillars (PAROLA 2013, 2017).

Concerning direct citizen enforcement, citizens are given standing to go to court or other review bodies to implement the law rather than just to redress personal damage. Indirect citizen enforcement means that citizens can contribute to the enforcement process through, for instance, citizen complaints (STEC, 2000, 130).

To conclude, this fourth pillar clarifies that it is not only the purpose of environmental authorities and public prosecutors to enforce environmental law, but that the public plays a role as well, to fulfil the environmental duty to conserve and protect the environment for future generations (STEC, 2000, 131).

Concerning article 8(2) in Escazú, it is important to underline that this article goes beyond Aarhus in the following paragraphs when is reducing barriers that undermine vulnerable communities' ability to exercise access to justice. Paragraph 3 provides that:

To guarantee the right of access to justice in environmental matters, each Party shall have, considering its circumstances: (...) (e) measures to facilitate the production of evidence of environmental damage, when appropriate and as applicable, such as the reversal of the burden of proof and the dynamic burden of proof.

In fact the agreement adopted the reversal of the burden of proof and the dynamic burden of proof following the doctrine and jurisprudence from different LatinAmerican states (CAPPELLI, 2018, p. 133)13.

13 In Brazil we can cite the following decision by the Superio Tribunal Justiça 2a Turma. Resp 1071741/SP. Rel. Min. Antonio Herman Benjamin, j. 16.12.10. 
DOI:

Then paragraph 4 of article 8 provides that to facilitate access to justice in environmental matters for the public, each Party shall establish:

(a) measures to minimise or eliminate barriers to the exercise of the right of access to justice; (b) means to publicise the right of access to justice and the procedures to ensure its effectiveness; (c) mechanisms to systematise and disseminate judicial and administrative decisions, as appropriate; and (d) the use of interpretation or translation of languages other than the official languages when necessary for the exercise of that right.

The most important for the Latin American society is letter (d) that provides that each Party shall establish a due care should be taken to help the individual that don't speak the official languages and this sentence is linked to the following paragraph saying that " 5 . In order to give effect to the right of access to justice, each Party shall meet the needs of persons or groups in vulnerable situations by establishing support mechanisms, including, as appropriate, free technical and legal assistance."

Concerning access to justice it is important to underline that unfortunately, the final version of the agreement did not contain a paragraph that provided the introduction of principle in dubio pro natura, "when in doubt, in favor of nature", that it was listed between other interpretation principles in the provisional version of the agreement. The deleted paragraph said "When implementing the present article, the Parties shall apply, (...) the following interpretation principles: in dubio pro natura, prevention, precautionary and non-regression, among others." In particular because the in dubio pro natura principle (CAPPELLI, 2016) means that in case of doubt, judges should provide an interpretation in favour of nature and there is a broad jurisprudence on this principle in Brazil ${ }^{14}$. In the word of Justice Antonio Herman Benjamin, Brazil Superior Court of Justice

In respect to environmental litigation, judges should consider applying new legal concepts like shifting or reversing the burden of proof. This is especially important in dealing with questions of causation, in which the principle in dubio pro natura should be applied in some circumstances. This means that in case of doubt, matters should be resolved in the way most likely to favour the environment.

${ }^{14}$ The jurisprudence of the Superior Tribunal of Justice in Brazil: Leading case: REsp 1.198.727/MG, $2^{\text {a }}$ T., Rel. Min. Herman Benjamin, j. 14.08.2012. Also REsp 1.356.207/ SP, 3aㅗ T., Rel. Min. Paulo de Tarso Sanseverino, j. 28.04.2015 and 9 others. Other example is the Biological Diversity Act 1998 of Costa Rica. 
DOI:

This principle was declared as a principle of international environmental law in the IUCN World Declaration on the Environmental Rule of Law (soft law), in the following term:

Principle 5: In Dubio Pro Natura In cases of doubt, all matters before courts, administrative agencies, and other decision-makers shall be resolved in a way most likely to favour the protection and conservation of the environment, with preference to be given to alternatives that are least harmful to the environment. Actions shall not be undertaken when their potential adverse impacts on the environment are disproportionate or excessive in relation to the benefits derived therefrom.

Although jurisprudence in Latin America has treated it as a synonym of the precautionary principle, it doesn't have to be confused with it, because it acts in the face of uncertainty when balancing fundamental norms or rights, while precautionary principle is applied in case of scientific uncertainty. In addition, in dubio pro natura can be used before and after the damage, while the precautionary principle is necessarily preventative, that is to say, it is assessed before the implementation of an activity capable of generating uncertain risks (CAPPELLI, 2018).

The analysed paragraph could mark a milestone in international environmental law, because judicial interpretation usually plays a significant role in the enforcement of the environmental treaties.

\subsection{ART 9 OF ESCAZÚ AGREEMENT: AN IMPORTANT STEPS FORWARDS!}

The new agreement is the first international binding treaty that specifically uses the term environmental human rights defenders ${ }^{15}$, guaranteeing the protection of their rights. It requires governments to take measures to prevent, investigate and punish threats and attacks against these community leaders.

\footnotetext{
15 There is no strict definition of human rights defenders because they can be anyone who act at any moment for any human rights. General Assembly Resolution A/RES/53/144 (8 March 1999) adopting the "Declaration on the Right and Responsibility of Individuals, Groups and Organs of Society to Promote and Protect Universally Recognized Human Rights and Fundamental Freedoms" - with this longer title is frequently abbreviated to "The Declaration on human rights defenders". But this declaration, is general, doesn't talk specially about the environmental human rights defenders https://documents-dds ny.un.org/doc/UNDOC/GEN/N99/770/89/PDF/N9977089.pdf?OpenElement
} 
DOI:

The Article 9 of Escazú called "Human rights defenders in environmental matters" provides:

1. Each Party shall guarantee a safe and enabling environment for persons, groups and organizations that promote and defend human rights in environmental matters, so that they are able to act free from threat, restriction and insecurity. 2. Each Party shall take adequate and effective measures to recognize, protect and promote all the rights of human rights defenders in environmental matters, including their right to life, personal integrity, freedom of opinion and expression, peaceful assembly and association, and free movement, as well as their ability to exercise their access rights, taking into account its international obligations in the field of human rights, its constitutional principles and the basic concepts of its legal system. 3. Each Party shall also take appropriate, effective and timely measures to prevent, investigate and punish attacks, threats or intimidations that human rights defenders in environmental matters may suffer while exercising the rights set out in the present Agreement.

The Global Witness report has underlined that in 2017 (GLOBAL WITNESS, 2017), 207 defenders were killed, and many more were attacked, threatened or criminalised for showing the courage to speak out for their communities, their way of life and our environment. It has been calculated that almost four environmental defenders were killed each week for protecting their land, forests, waterways and wildlife (GLOBAL WITNESS, 2017). Moreover, the Global Witness has reported that plagued by increasingly deadly conflicts over natural resources (WORLD RESOURCES INSTITUTE, 2018), Latin America is the most dangerous region in the world for those who stand up to protect their environments and in the Caribbean, threats against activists, are also intensifying. In the words of the report:

Once again, Latin America saw the highest number of murders, accounting for almost $60 \%$ of the total. According to Global Witness data, Brazil recorded the most killings of any country ever with 57 people killed, $80 \%$ of them while protecting the natural riches of the Amazon. In Colombia 24 defenders were murdered in 2017, as conflicts over land raged on. Mexico and Peru saw a jump in killings from three to 15 and two to eight respectively. There were fewer murders in Honduras - five compared to 14 in 2016 - but the growing repression of civil society has restricted what defenders can say and do. Nicaragua registered the most murders per capita, with four defenders killed" (GLOBAL WITNESS, 2017).

Moreover Agribusiness, that is the greatest business activity in Latina America was identified by the report as the most dangerous sector, overtaking mining for the 
DOI:

first time ever, with 46 defenders killed protesting against the way goods we consume are being produced. Sadly the report also underlines that "widespread impunity makes it difficult to identify perpetrators", but Global Witness was able to link government security forces to 53 of the killings, and non-state actors to $90 "$.

Thus, the introduction of the first binding provision on human rights defenders in environmental matters in a region will not only help reduce violence against defenders but also will push, we hope, governments to take measures to prevent, investigate and punish threats and attacks against these community leaders.

\section{CONCLUSION}

The Escazú is open for signature since 27 September 2018 at the UN headquarters in New York (FARN, 2018). Currently, ${ }^{16}$ it counts already 16 signatories but no ratification. The Agreement will enter into force once 11 of the 33 countries that comprise the Latin American and Caribbean region have ratified it (UNITED NATIONS, 2018). How it has been underlined "Success in realising the Agreement's provisions will depend not only on citizens' active participation in subsequent decision-making processes, but also on civil society's ability to act as watchdog and monitor governments' progress." (WORLD RESOURCES INSTITUTE, 2018)

It is possible, in conclusion, to affirm that the Aarhus Convention is, at the moment, "the most ambitious venture in the area of environmental democracy" (KOFI, 1998) within international environmental law. However, when the Escazú Agreement will enter into the force, this document it will be the most advanced international instrument to implement Principle 10 of the 1992 Rio Declaration on Environment and Development and to combat inequality and discrimination and to guarantee the rights of every person to a healthy environment.

In conclusion, if Escazú Agreement will have just half of the legal influence that the Aarhus had among the signatory parties, we will hear about it for long!

16 January 2019 
DOI:

\section{REFERENCES}

ALONSO, Carlos José de Miguel. Histórico, avanços e repercussão do Acordo Regional na América Latina. Exposição realizada no 130 Congresso de Direito Ambiental dos países de língua portuguesa e espanhola. São Paulo, 26 de maio de 2018.

ANNAN, K. Foreword. In: S. STEC, S. CASEY-LEFKOWITZ (Eds.), (p. 17). New York, Geneva, United Nations Publication, 2000.

ANTON, D. K. Observations about expanding public participation in the international environmental law-making process. Public Law and Legal Theory Working Paper, Series Working paper n. 112, 8, June 2008, p. 8. Available at www.ssrn.com/abstract $=1145066$.

The Internationalization of Domestic Law: The Shrinking Domaine Réservé". American Society of International Law Proceedings, 1993 p. 553

BALMACEDA, J.L., "Hacia un compromiso medioambiental regional", Diario Financiero Online, 14 August 2012, Available at: http://www.df.cl/hacia-uncompromiso-medioambiental-regional/prontus_df/2012-08-13/175635.html.

BARCEN, A. Preface to the Escazú Agreement, Available at: https://repositorio.cepal.org/bitstream/handle/11362/43583/1/S1800428_en.pdf, 2018

BELL, D. R. Sustainability through democratisation? the Aarhus convention and the future of environmental decision-making in Europe. In: J. Barry, B. Baxter, \& R. Dunphy (Eds.), Europe, Globalisation and the Challenge of Sustainability. London, Routledge. 2004. p. 98

CAPPELLI, S; BORN, R, RIBEIRO GOES, H. O Acordo de Escazú e os direitos de acesso em temas ambientais: o potencial do acordo para o direito ambiental brasileiro. Revista de Direito Ambiental ano 23, n. 91, jul-set 2018, p. 133

Workshop on public participation in international negotiations on environmental matters United Nations, March 2016 Santiago, Chile

CRAMER, B. W. The Human Right to information, the environment and information about the environment: from the Universal Declaration to the Aarhus Convention. Communication Law and Policy, 14, 2009 p. 98

DECLARATION BY THE ENVIRONMENTAL MINISTERS, of the region of the United Nations Economic Commission for Europe (UN/ECE), 4th Ministerial Conference "Environment for Europe", Aarhus, Denmark, 23-25 June 1998, para. 40.

DONALD, K. A. Observations About Expanding Public Participation In The International Environmental Law-Making Process. The Social Science Research Network Electronic Paper Collection. 2008 Available at 
DOI:

www.ssrn.com/abstract=1145066.

ECKERSLEY, R. The Green State: Rethinking Democracy and Sovereignty. Cambridge, MIT Press. 2004 p. 193-194

ECLAC, Marcos A. Access to information, participation and justice in environmental matters in Latin America and the Caribbean. Situation, outlook and examples of good practice, October 2013, United Nations, Santiago, Chile. p.65

. Orellana, Typology of instruments of public environmental international law, October. 2014 United Nations, Santiago, Chile.

Sustainable Development 20 Years on From the Earth Summit. Progress, gaps and strategic guidelines for Latin America and the Caribbean. United Nations. 2012 Available at http://repositorio.cepal.org/bitstream/handle/11362/1427/S1100457_en.pdf?sequenc $e=1$

. Economic Commission for Latin America and the Caribbean, The Document on Regional Agreement on Access to Information, Participation and Justice in Environmental Matters in Latin America and Caribbean, The Escazú Agreement 2018. Available at: https://repositorio.cepal.org/bitstream/handle/11362/43583/1/S1800428_en.pdf,

.Workshop on public participation in international negotiations on environmental matters Panel on environmental justice and access rights for sustainable development in Latin America and the Caribbean, Seminars and Conferences Series No. 84, United Nations. 2016 p. 16.

FARN. Latin America and the Caribbean adopt a historical legally-binding Agreement for the Protection of Environmental Rights. In: IUCN. Available at: https://www.iucn.org/news/commission-environmental-economic-and-socialpolicy/201804/latin-america-and-caribbean-adopt-historical-legally-bindingagreement-protection-environmental-rights.

GASTÓN MÉDICI. C., EL ACUERDO ESCAZÚ: La Implementacion del Principio 10 de Rio en America Latina y el Caribe, , Revista Catalana de Dret Ambiental. Vol. IX N. 1 2018. p. 1

GLOBAL WITNESS, Report 2017, Available at: https://www.globalwitness.org/en/campaigns/environmental-activists/at-what-cost/

GUERRA, Sidney. Curso de Direito Internacional Público. 11. Ed. São Paulo: Saraiva, 2017.

Direito Internacional Ambiental. Rio de Janeiro: Freitas Bastos, 2006.

HAYWARD, T. Constitutional environmental rights: a case for political analysis. Political Studies, 48, 2000. p. 558. 
DOI:

IUCN World Declaration on the Environmental Rule of Law, 2017 Available at: https://www.iucn.org/sites/dev/files/content/documents/world_declaration_on_the_en vironmental_rule_of_law_final_2017-3-17.pdf.

JOHANNSDOTTIR, A. Considerations on the Development of Environmental Law in the Light of the Concept of Sustainable Development. YM, 2007, p. 27.

KOFI, A., UNECE, Introducing the Aarhus Convention, available at www.unece.org/env/pp/welcome.html 1998. (quoting Kofi A.).

KRAVCHENKO, S., SKRYLNIKOV, D., BONINE, J. E.. Access to justice in cases involving public participation in decision-making. In: S. STEC (Ed.), Handbook on Access to Justice under the Aarhus Convention. Szentendre, Unites Nation Publication. 2003. p. 27

MARSHALL, F. Two Years in the Life: The Pioneering Aarhus Convention Compliance Committee 2004-2006. International Community Law Review, 8, 2006 p. 126

PALLEMAERTS, M. Human rights and democracy in the face of international environmental issues, 2003 available at: www.coe.int/T/E/Com/Press/colloquies/2003/Pallemaerts_report.asp.

PALLEMAERTS, M. Introduction: human rights and environmental protection. In: $M$. Déjeant-Pons, M. Pallemaerts (Eds.), Human Rights and the environment. Strasbourg, Council of Europe. 2002 p. 18

Proceduralising environmental rights: the Aarhus Convention on Access to Information, Public Participation in Decision-Making and Access to Justice in Environmental Matters in a Human Rights Context. In: Human Rights and the Environment Proceedings of a Geneva Environment Network roundtable. Geneve, Geneva Environment Network. 2004 p. 19.

PAROLA, G. Democracia Ambiental Global. Rio de Janeiro. Multifoco. 2017

Democracia Ambiental na América Latina: uma abordagem comparada. Rio de Janeiro, Multifoco. 2016

Environmental Democracy at Global Level. London: Versita. 2013

PRIEUR, M. Le principe de non régression en droit de l'environnement, condition du développement durable, RADE, 2013

REDGWELL, C. Access to Environmental Justice. In: F. Francioni (Ed.), Access to Justice as a Human Right. Oxford, Oxford University Press. 2007 p. 159

STEC, S. \& CASEY-LEFKOWITS S. The Aarhus Convention: An Implementation Guide. New York and Geneva, United Nations. 2000 p. 1 
DOI:

UNECE, (United Nations Economic Commission for Europe). Convention on Access to Information, Public Participation in Decision- Making and Access to Justice in environmental Matters, Participants, June 25, 1998, 38 I.L.M. 517 (1999), entered into force Oct. 30, 2001.

UNITED NATIONS. Observatory on Principle 10. Regional Agreement on Access to Information, Public Participation and Justice in Environmental Matters in Latin America and the Caribbean. Available at: https://observatoriop10.cepal.org/en/treaties/regional-agreement-access-informationpublic-participation-and-justice-environmental

WATES, J. The Aarhus Convention: a Driving Force for Environmental Democracy. Journal of European Environmental Planning Law, 2005, p. 2

WORLD RESOURCES INSTITUTE, The Escazu Convention: A Historic Step Forwards for Environmental Rights in Latin America and the Caribbean, Available at: www.accessinitiative.org, 2018 